\title{
To Be Part of the Song: Tuning Toward the Right Notes in Sing, Unburied, Sing
}

\author{
Hannah Bonner
}

Sing, Unburied, Sing. Ward, Jesmyn. Scribner, 2017. 304 pp. \$ 26.00 Hardcover. Ebook available.

Jesmyn Ward's third novel Sing, Unburied, Sing (2017) marks her second National Book Award. Her first was for the critically acclaimed Salvage the Bones (2011), a novel that follows fifteen-year old Esch in the days leading up to Hurricane Katrina, a young girl who devours Edith Hamilton's Mythology and idolizes Io and Artemis, a young girl whose mother died giving birth to her youngest brother, and a young girl who is pregnant by a boy who does not publicly acknowledge her, a boy whose "eyes are so black...they are a night without stars" (146). Sing, Unburied, Sing similarly delves into childhood, the Mississippi landscape, the fractures of family failure, but also the ways in which a family's love can tether us to one another so completely that we almost catch and complete one another's breaths. While no goddesses or nymphs dapple these pages, there are ghosts in this novel, reminiscent of other Southern writers such as William Faulkner and Allan Gurganus or Octavia E. Butler's science-fiction. The novel, divided into chapters narrated by different characters, primarily follows Jojo, a young teenage boy who lives with his toddler sister, Kayla, his mother, Leonie (who struggles with an addiction to crack), and his maternal grandparents. Jojo's grandmother, Mam, is slowly dying of cancer and his father Michael is in prison, on the verge of being released. The story follows Jojo as Leonie prepares for their trip, a $21^{\text {st }}$ century Odyssey, to bring Michael home from Parchman Farm, the Mississippi State Penitentiary. Told in blisteringly beautiful 


\section{IJCS}

prose, Ward welds the past and the present together to explore race, poverty, family, and the sonorous Mississippi landscape, a landscape perpetually on the cusp of fullthroated song.

The novel begins with a sacrifice on Jojo's thirteenth birthday. He and Pop, his grandfather, slaughter a goat, leading Jojo to reflect, in the opening line, "I like to think I know what death is" (1). This sentence might seem a bit presumptuous for a young boy just stepping across the threshold into his teenage years. And while it is clear that Jojo is still learning about the messiness of death (he throws up outside after they skin the goat), he's also battling the oncoming literal death of his grandmother and the figurative death of his mother, who now he just calls "Leonie," after so many disappointments and absences: "Before she started snorting crushed pills. Before all the little mean things she told me gathered and gathered and lodged like grit in a skinned knee" (7). Jojo is fiercely resilient in the face of Leonie's increasing drug dependence. Resilience manifests for him in ardent familial love. He is a boy deeply devoted to his sister Kayla. He's the one she reaches for when she wakes from a nap, the one whom she palms when she's sleepy, and the one who steals crackers for her so she can have a snack when Leonie has, predictably, forgotten. Their constant connection manifests telepathically when Jojo realizes, "I know by the way she's studying me, her little eyes round as marbles, calm in her seat, rubbing her seat belt clasp with her other hand, that she has it. Like me...Because she can look at me and know what I'm thinking" (176). His name, in her fragmented baby babble, is her recurring refrain. Jojo, too, murmurs to Kayla, sometimes inaudibly to his mother, further distancing her from those she might love most. But Leonie knows that their bond is immutable. Towards the end of the novel she notes, "They are each other's light" (151).

It is partly the bond that Jojo and Kayla share that causes Leonie to distance herself as a mother from her young children, showcasing how loss can ultimately separate us from the people we might otherwise need most. Several years ago, Leonie's brother, Given, was shot by a white local, a cousin of Michael, father of her children. The police ruled the death a "hunting accident," and Given's killer goes free. When Leonie gets high, Given often appears to her, though initially it is unclear if he is an apparition or a drug induced hallucination. Unable to untangle herself from the acuteness of her grief, Leonie is mired in her past, in her brother who steadily, silently, watches over her. Given's ghost says nothing to Leonie and sometimes she's unable to assess whether his straight face connotes judgement, sympathy, or disapproval. Despite his opacity, Leonie craves him and his memory just as much as the drugs that eclipse all loss and her acres of agony. On the drive to get Michael, Kayla kicks Leonie's seat, causing Leonie to snap and "slap her leg so hard my palm stings. Jealousy twins with anger. That girl: so lucky. She has all her brothers" (197). Leonie's spates of abuse stem from a deep despair of never being able to go back to when her family was whole. Given's death not only shatters Leonie's family, but also stymies her ability to grow and move forward. While Mam tells Jojo that Leonie does love him, she also plainly states, "she ain't got the mothering instinct. I knew when you was little and we was out shopping, and she bought herself something to eat and ate it right in front of you, and you was sitting there crying hungry. I knew then" (233). This 
novel is not just about family, but about the way loss transforms family and how those we might depend on leave us grasping for air like fish mired on land. Leonie is incorrigible - solipsistic and selfish in her loss. She winds around her pain like Ouroboros eating its tail whole.

In an interview with Natalie Moore in September 2017, Moore asked Ward "what it was like writing [Leonie]" when she is, in many ways, such an unlikeable character. Ward admits that she "didn't like her at first," but that "after discovering who Given was to Leonie...then I felt like I understood her motivation...she's never really attempted to confront her grief... and that pain is so great that she can't see past it to be less selfish, to be the mother she needs to be to her children." Ward is an astute and empathetic writer, as much as she is a lyricist. When Leonie reaches her breaking point, she begs Michael to accompany her running away from home and all the responsibilities being entails, internally reflecting, "We hold hands and pretend at forgetting" (274). It is easier to forget than to remember - Leonie's addiction is akin to the Lotus-eaters who tempt Odysseus's men with a lifetime of never yearning to return home.

In her memoir Men We Reaped (2013), Ward stated that she "wanted to be [her] own heroine" (86). In Sing, Unburied, Sing, this heroism, however imperfect at times, is fully realized in her careful attention to each character's story, to giving each character a fully-realized voice. Ward imbues her characters with inherent dignity even when they are struggling from all sides. Leonie and Michael's emaciated bodies are "fish-thin, slender as two gray sardines, packed just as tight" (277). Ward renders their delicacy and their dependence for one another deftly in her similes. Even Richie, the ghost of a young boy who knew Pop and died after escaping from Parchman, gets his own chapters, his own story, his own promise for resolution and reconciliation. He whispers to Jojo like the Mississippi pines and sings incessantly, telling Jojo, "I'm going to be part of the song" (183). What song Richie refers to is unclear, but his desire to join the harmony of an enveloping song evokes Apollo's music and the term stimmung. Writing on the German word, Denis E. Cosgrove notes that "stimmung captures this 'tuning' of a vital earth to a resonate, universal harmony...The figure of Apollo thus prompts the conception of a unified world" (3). Even when it seems like the sphere of these characters' connecting stories might crack to a crescent moon, Ward never forsakes her ghosts, never forsakes the history of their past. Richie's and Given's stories get told alongside the living.

In this book Ward stands up to stare squarely at the people whose stories often get overlooked or ignored. Sing, Unburied, Sing is Ward's requiem for these individuals who press on, who falter, who open their mouths wide to join the universal harmony even when the whole world is keening.

\section{Works Cited}

Cosgrove, Denis E. Apollo's Eye: A Cartographic Genealogy of the Earth in the Western Imagination. JHU Press, 2001.

Family Action Network. “Jesmyn Ward Interviewed by Natalie Moore.” YouTube, 7 Oct. 2017, www.youtube.com/watch?v=RmQyzfVuSfU. 
70 IJCS

Ward, Jesmyn. Salvage the Bones. Bloomsbury, 2012. 